\title{
LATE QUATERNARY AND HOLOCENE FAULTS OF THE NORTHERN GULF OF CORINTH RIFT, CENTRAL GREECE
}

\author{
Valkaniotis S. ${ }^{1}$ and Pavlides S. ${ }^{1}$ \\ ${ }^{1}$ Aristotle University of Thessaloniki, Department of Geology, 54124, Thessaloniki, Greece, \\ valkaniotis@yahoo.com,pavlides@geo.auth.gr
}

\begin{abstract}
New results for the recent tectonic activity in the northern part of the Gulf of Corinth rift are presented. Geological mapping and morphotectonic study re-populate the area of study with numerous active and possible active faults. The area is dominated by individual and segmented normal faults along with major structures like Marathias and Delphi-Arachova faults. The results are in accordance with recent studies that reveal a more complex and wider structure of Corinth Rift to the north.

Keywords: Active Tectonics, Seismic Hazard, Normal Faults, Extension, Delphi Fault.
\end{abstract}

\section{Пєрі́ $\eta \psi \eta$}

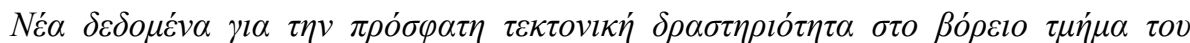

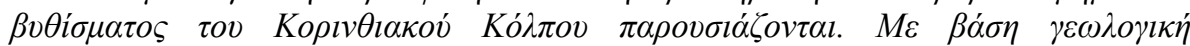

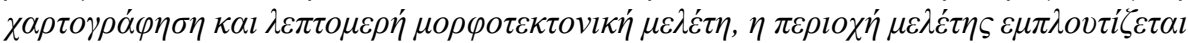

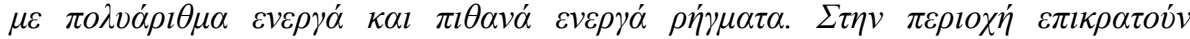

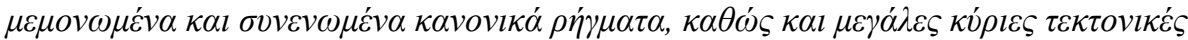

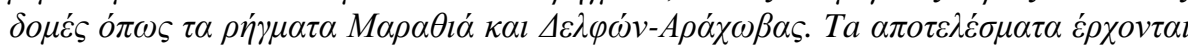

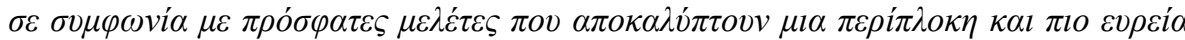

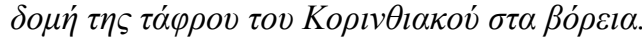

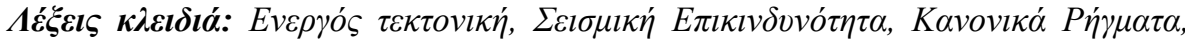

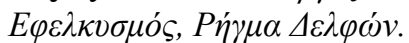

\section{Introduction}

The Gulf of Corinth Rift is a rapidly expanding intra-continental extensional rift in a W-E setting, across the Alpine formations of the External Hellenides Geotectonic units of Pindos, Vardoussia, Parnassos and Beotia (Celet, 1962; Doutsos et al., 1988; Ori, 1989; Armijo et al., 1996). The initiation of the rift is estimated at the Late Pliocene (3.3 Ma - Leeder et al., 2012) and is currently involving extension along segmented and individual normal fault of W-E to WNW - ESE strike in a broad zone from Patras Gulf to the west up to Beotia and Asopos rift to the east (McNeil et al., 2005; Tsodoulos et al., 2008; Taylor et al., 2011; Bernard et al., 2015). Evidence of the active deformation state and rate of the Corinth Rift are numerous and strong historical and recent earthquakes, intense microseismic activity and extension measured by GPS and surveys (Sebrier 1977; Ambraseys and Jackson 1990; Hatzfeld et al., 2000; Papadopoulos et al., 2000; Bell et al., 2009; Lambotte et al., 2014). Earlier interpretations of the Corinth Rift as an asymmetrical basin with fault activity concentrated on the southern north-dipping faults are being revised as a more complex basin structure is revealed from detailed offshore surveys. The scope of this study is to fill a gap of onshore fault activity in the northern part of the rift in order to assess seismic hazard in a 
poorly mapped area, further understand the structure of Corinth rift and document the transitional zone between the Gulf of Corinth and the northern active extensional basins of Kifissos, Evoikos Gulf and Spercheios Rift.

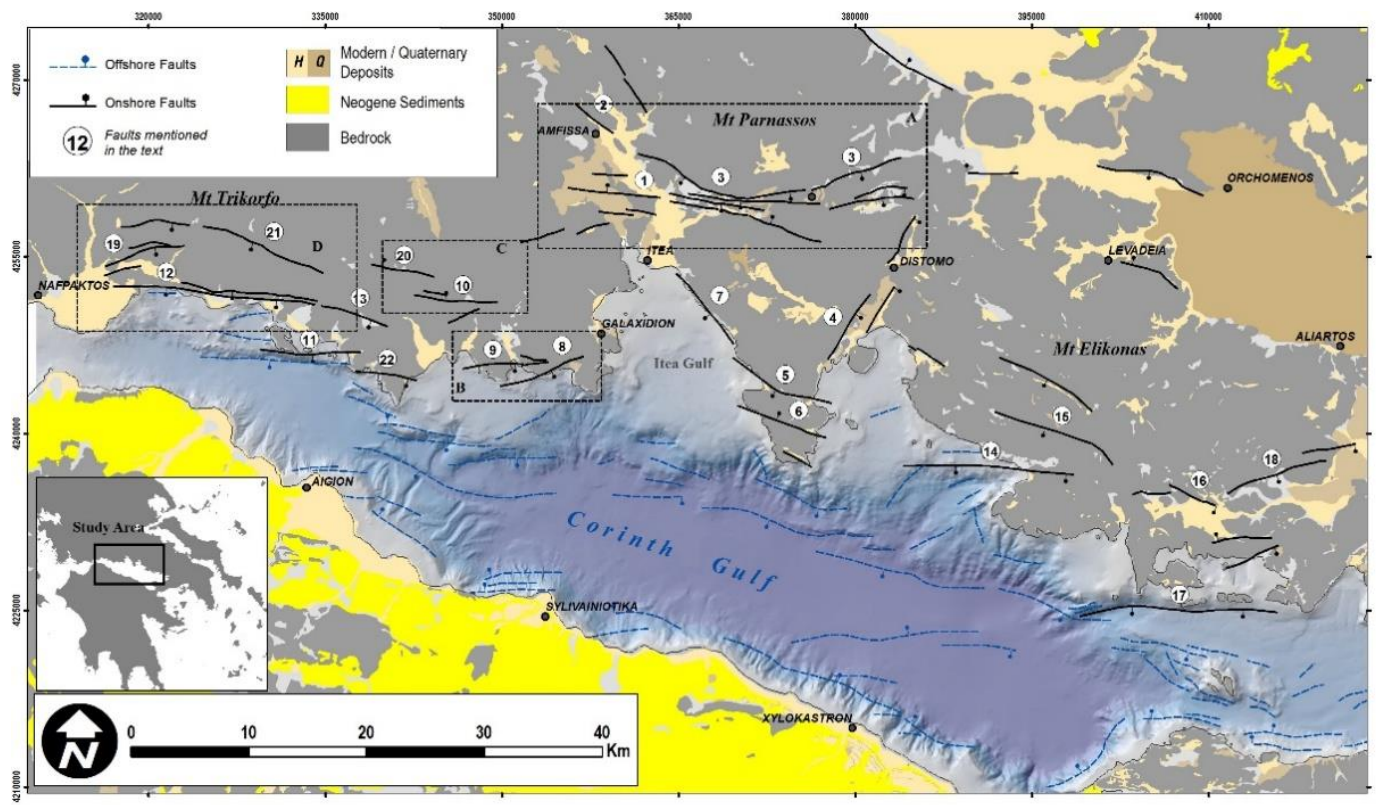

Figure 1 - Active and possible active faults of the northern Gulf of Corinth. Fault numbers are in accordance with Table 1. Bedrock formations with dark grey color and post-alpine sediments with light grey colors. Index boxes A, B and C show location of Figures 2 and 3. Seafloor topography of Corinth Gulf is shown with shaded relief. Grey fault lines denote offshore faults from Stefatos et al. (2002), McNeil et al. (2005) and Bell et al. (2009).

\section{Active Faults of the Area}

\subsection{Delphi - Arachova Fault Zone}

The Delphi - Arachova fault zone is a large active extensional structure north of the central part of the Gulf of Corinth that defines the southern slope of Parnassos Mountain (Péchoux, 1977; de Boer and Hale, 2000; Piccardi, 2000). The main Delphi - Arachova fault consists of two normal fault segments dipping south, with a length of about $10 \mathrm{~km}$ each (Figure 1 and 2). The Delphi fault to the west is clearly defined by a large morphological scarp from the Amfissa-Itea plain to the east of Delphi archaeological site with a trend of NW-SE to W-E. The Arachova fault to the east, is less accurately defined and mapped due to the large slope debris and avalances and the erosivity of the flysch basement formation. Fault measurements and morphotectonic features show a complex normal fault zone with an oblique slip (fault lineations $60^{\circ}$ to the west). Overal morphological scarp reaches up to 500 meters in the Plistos Valley, with a post-glacial striated fault scarp of up to 10 meters. The fault zone is distributed with multiple parallel fault scarps along strike (Figure 3) converging at a depth to the main Delphi fault surface, as is evident in the area of the Delphi Oracle (Piccardi, 2000; Valkaniotis et al., 2011). The Delphi Oracle site complex is situated inside the fault zone on the hanging wall and is disrupted by at least two historical surface ruptures in $373 \mathrm{BC}$ and 1870 (de Boer and Hale, 2000; Piccardi et al., 2008). The most recent activation of the fault zone was in the 31 July/1 August 1870 earthquake cluster with the main event having a possible magnitude of $M=6.7$, one of the strongest historical earthquakes in the central Greece (Ambraseys and Pantelopoulos, 1989; Papadopoulos et al., 2000; Ambraseys, 2009). 
The western limit of Delphi-Arachova fault zone is defined by the southern limit of entrenching of the meander of Skitsa River. There were found no evidence of propagation and linkage of the fault zone to the Amfissa active fault to the north-west. To the east, the limit of the fault zone is obscure, with the probability of the NE-SW propagation through Parnassos Mt. The Plistos watershed is propagating to the east, capturing drainage that previously flowed to the east (Figure 3 ). This is explained to be a result of the deepening of the basin in the central and western parts of the basin due to the subsidence in the hangingwall section of the fault.

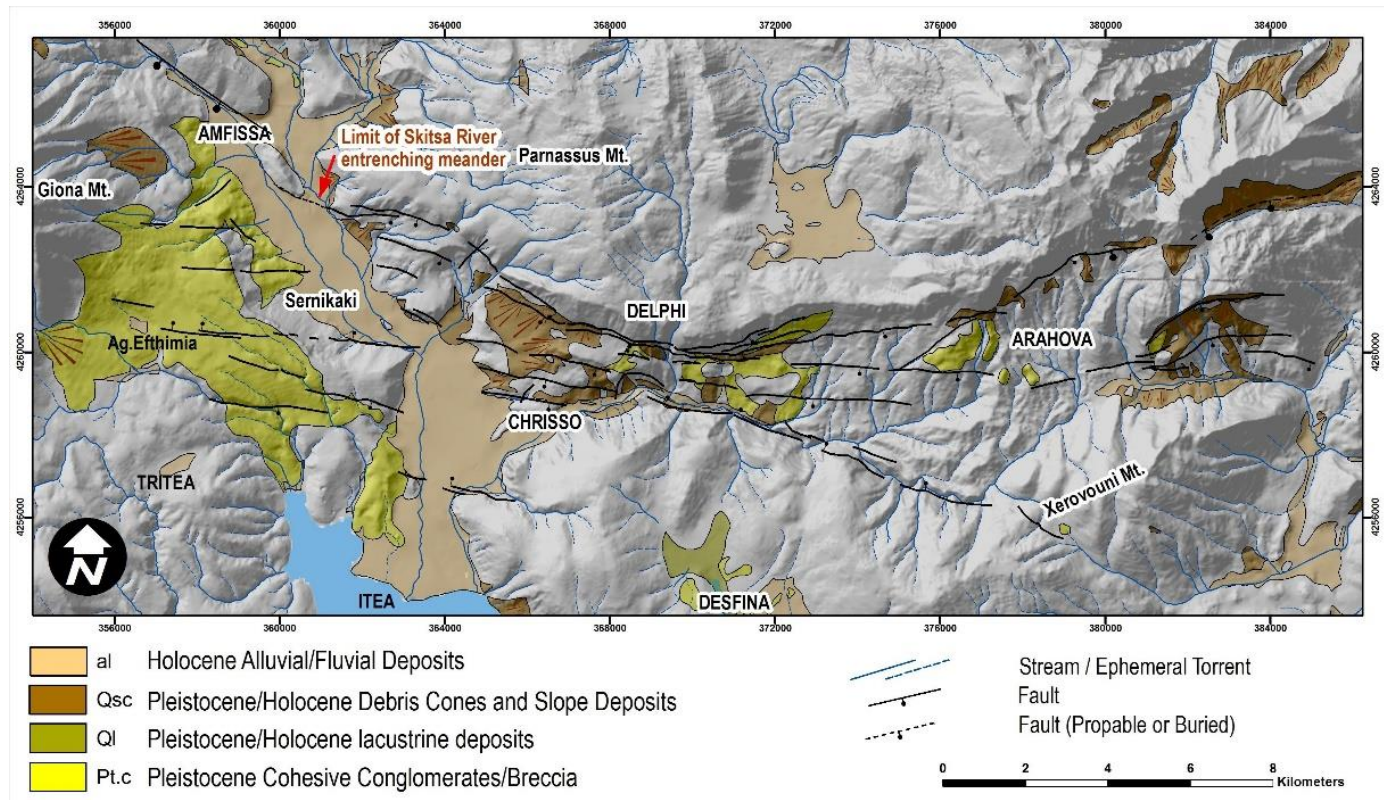

Figure 2 - The Delphi - Arachova Fault zone. Neogene and Quaternary sediments from this study and IGME Geological Maps.

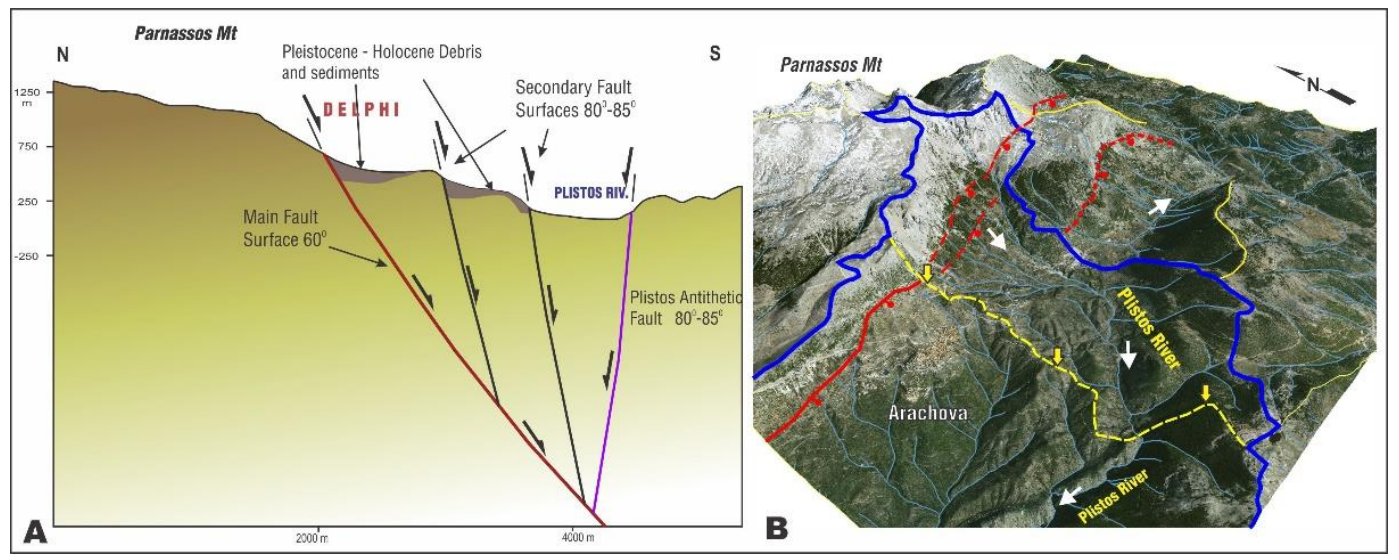

Figure 3 - A) Interpretive section with the tectonic model of the Delphi-Arachova Fault Zone. B) The eastern half of Plistos valley. Plistos basin (blue line) is expanding eastwards, capturing drainage that previously flowed to the east (yellow dotted line). Arachova fault and possible extensions with red line.

A complex array of normal and strike-slip faults with a W-E/WNW-ESE strike and north-dipping was mapped displacing Quaternary sediments in the Agia Efthimia plateau. The relation of this fault complex with the Delphi-Arachova Fault Zone is unkown, with a probable interpretation as an 
antithetic western extension. Agia Efthimia fault is believed to be a candidate for the 1580 historical earthquake (Papadopoulos et al., 2000; Ambraseys, 2009).

\subsection{Western Corinth Gulf}

In the western part of the area studied, multiple onshore and coastal en-echelon normal faults were mapped (Figures 1 and 4). The largest structures are the Marathias and Trizonia fault zones, dipping to the south in the western rim of the Gulf of Corinth. Marathias fault has an evident morphological scarp trending W-E along the coast.

The Kokkinovrachos fault (Figure 4) south of Lidoriki, is a north-dipping normal fault antithetic to the general fault setting (Valkaniotis, 2009). It is interpreted as an inherited structure, re-activated in the current stress regime, with evidence of Late Quaternary-Holocene activity (recent colluvial sediments and a possibly post-glacial fault scarp).

Along the northern coast, the coastal fault zones of Agioi Pantes and Galaxidi are found to the east of Eratini (Figure 4). The Galaxidi fault has a WSW-ENE strike and terminated onshore to the east of Galaxidi town. A continuous post-glacial striated fault scarp along the limestone bedrock is evident for a recent (Holocene) activation of the fault. Parallel to the Galaxidi fault is the Agioi Pantes fault, dipping also south, and both forming an overlap zone (ramp structure in Figure 4).
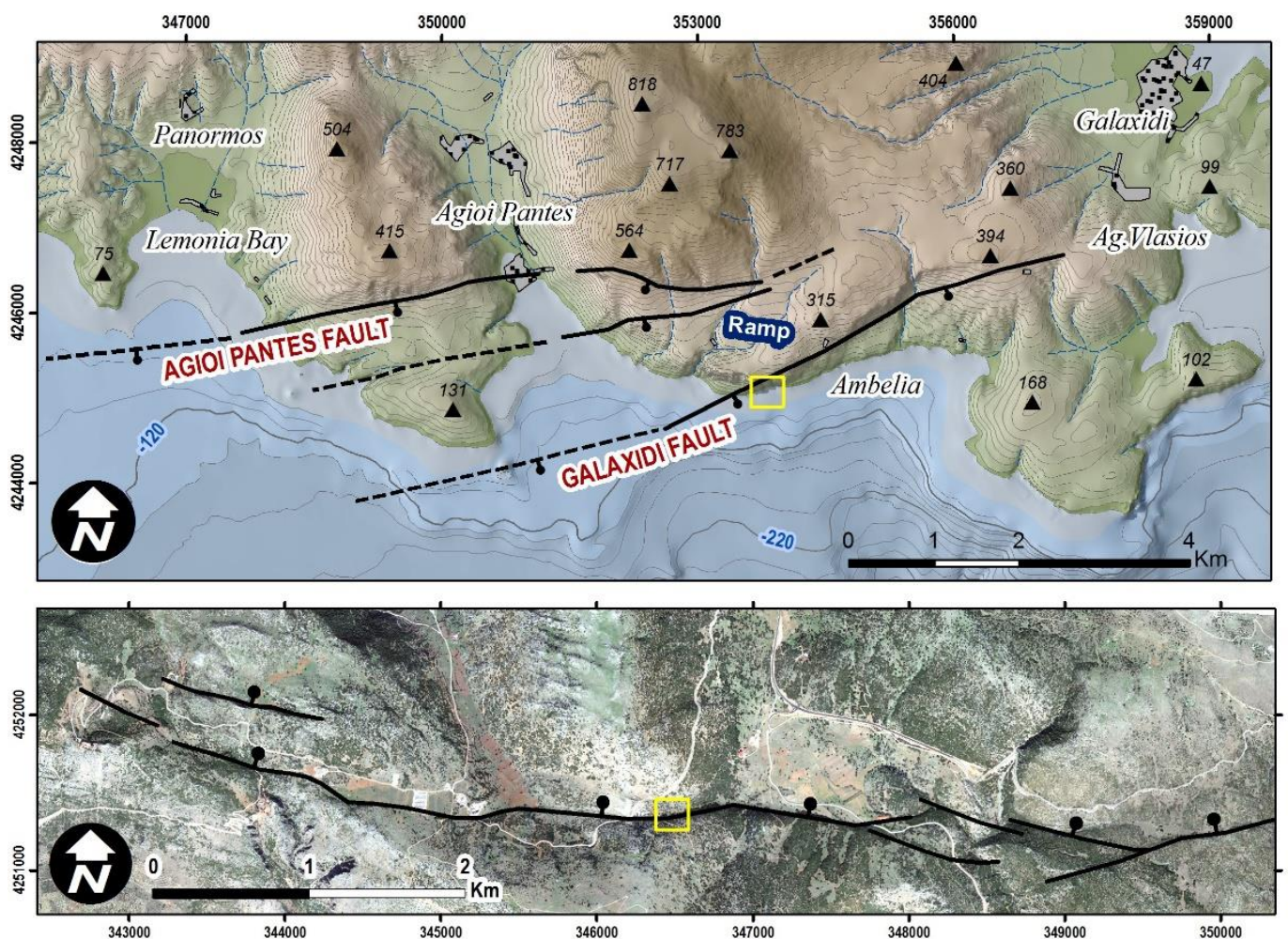

Figure 4 - Above: The Agioi Pantes and Galaxidi Fault Zone. A ramp structure is formed in the overlap area between the two faults. Elevation and bathymetry contour interval is $20 \mathrm{~m}$. Below: Kokkinovrachos Fault. Normal Fault scarps mapped with thick black lines and dot on downthrown side. 

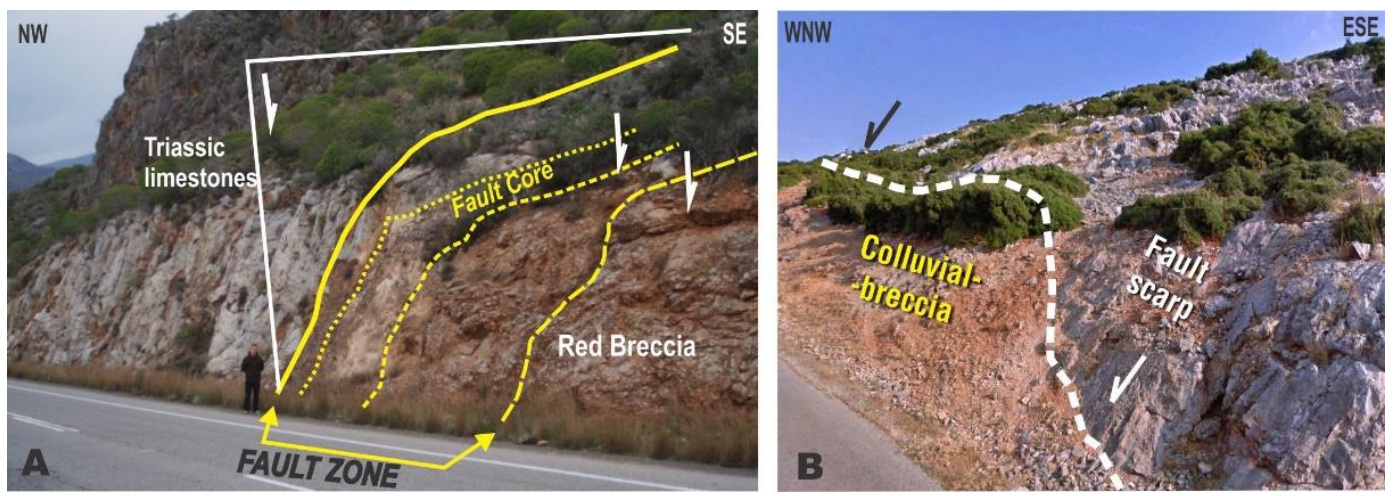

Figure 5 - A) Fault zone detail of the Galaxidi Fault. B) Fault scarp of Kokkinovrachos Fault. Site of images is shown in Figure 3.

The inland faults in the western area, like Kokkinovrachos, Amygdalea and less likely Kallithea Fault, could be the source of the $1909 \mathrm{M}=6.3$ Fokis earthquake, as the damages and macroseismic intensities correlate with a northern sited fault and possibly north-dipping (Ambraseys and Jackson, 1990; Valkaniotis, 2009).

Using the morphotectonic approach to study the faults in the area is a useful method to assess the activity of the faults. An example is shown in Figure 6, for the western part of the area, between Mornos fan and Eratini. The lesser order basins and drainage in Trikorfo mountain area were analysed. The hypsometrical integral values show a non-mature state of the basins (values $>0.5$ ), and correlate with incision and erosion due to the higher deformation in the central part of the footwall of Marathias, Trizonia and Marathakia faults. SL-index values measured along the streams also indicate erosion and uplift in the footwall of these faults. A high value anomaly of the SL-index to the central part of the area, not correlated with lithological changes, hints to the presence and possible deformation in the Trikorfo fault zone.
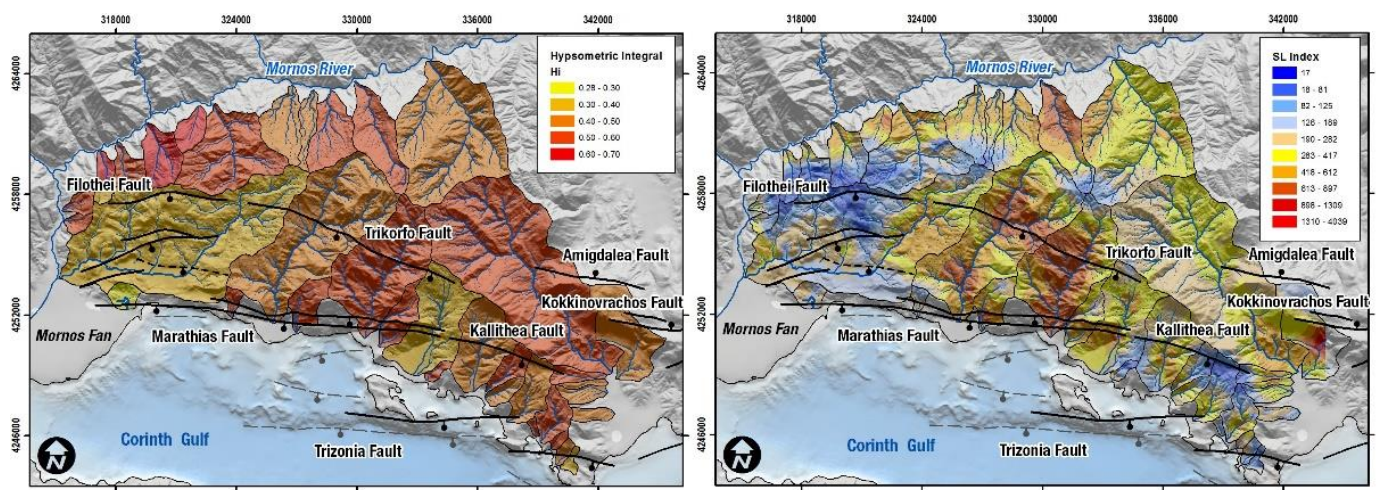

Figure 6 - A) Drainage basins in Trikorfo area, classified with hypsometric integral (Hi) values. Major faults are also shown. B) SL-index values in the same area. High values (red) indicate rapid uplift and erosion in the footwall drainage.

\section{Central Part - Antikira Gulf}

In contrast to the southern part of Corinth Rift, the northern part is characterised by a complex and variable fault structure, possibly related to the influence of inherited bedrock structures and older stress regimes. A fault structure irregular to the general setting of the Corinth Rift is the Antikira fault in the western rim of the Antikira Bay, in the central part of Corinth Gulf. The Antikira normal fault has a NE-SW strike and dips to the east. It forms a steep morphological scarp of 100-300 meters height. The 
fault has been mapped and described earlier by Sebrier (1977), but erroneously was recognised as a reverse structure (Figure 7B). Field investigation in this study, along the fault and in the original site that Sebrier describes reveal a normal fault, that possibly has been recentrly re-activated in the present stress regime. A sketch of the site (near the road Desfina - Antikira) is shown in Figure 7. The local curvature of the fault plane that is exposed at the specific site leads to a flipping of the fault surface to the west and measurements taken there show a reverse component. No evidence for a reverse fault zone was found elsewhere along the fault. Measurements in striated fault surfaces show at least one older phase with horizontal dextral striations, and the recent normal-oblique striations. The last phase of striations (NNE-SSW direction of extension - fit to present state of extension), Late Quaternary and Holocone sediments on the hangingwall, and the morphology of the fault scarp lead to a characterization of the fault as possible active, with at least Late Quaternary activity.
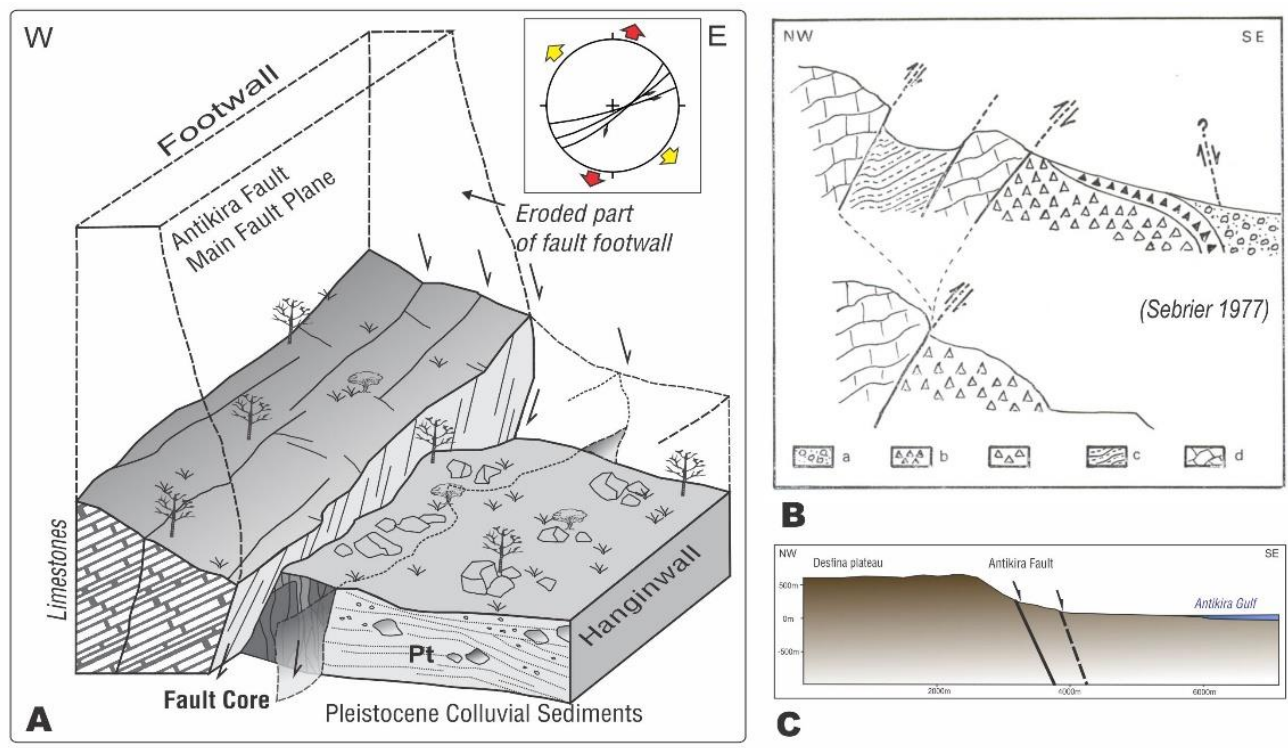

Figure 7 - A) Scetch based on field observations, explaining the mis-labeling of Antikira fault as reverse by Sebrier (1977). The curvature of the fault surface. B) Original sections at Antikira fault from Sebrier (1977). C) Profile of central section of Antikira Fault.
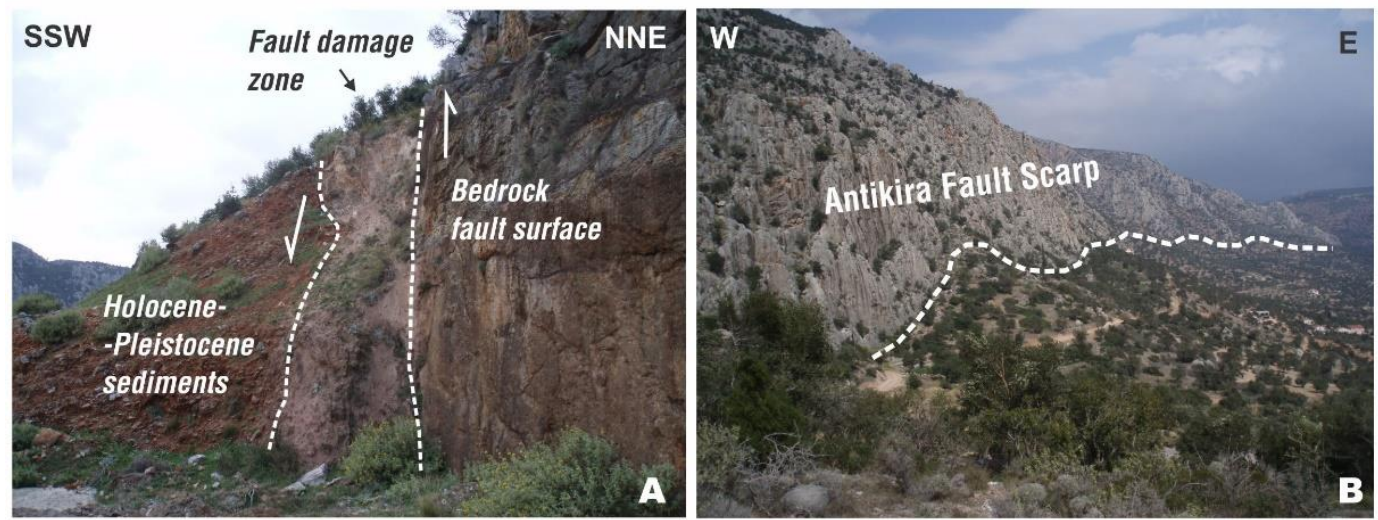

Figure 8 - Examples of normal faulting in the northern Gulf of Corinth Rift. A) Excavation outcrop of Amfissa Fault to the north-west of the city of Amfissa. B) The Antikira Fault scarp in the western side of Antikira Gulf. 
Evidence of NE-SW faults were also found to the north, along the narrow valley corridors that pass through Distomo, up to the east of Delphi-Arachova fault zone, without any large fault structure to be evident. This is interpreted as an older tectonic structure or a lower crust anomaly.

\section{Discussion -Results}

Recent studies and new data from the present research reveal a complex structure of the northern part of the Gulf of Corinth rift and populate the poorly mapped region with numerous and new faults. A summary of the main active and possible active fault for the area of research is shown in the Table 1. Faults are classified with categories according the last evident activation, based on seismicity, historical earthquakes, geological data and morphotectonic features. As Holocene category, we classify faults that exhibit post-glacial activation (post-glacial striated fault surfaces, hanging wall colluvial sediments or modern seismicity) an age which corresponds to 18.000 years BP for the Aegean. Slip rate data are scarce and those that can be measured (fault scarps) show a mostly low to very low slip rate of 0.1-0.2 mm/yr and a large repeat time (Valkaniotis, 2009), in accordance with active faults of mainland Greece. Marathias and Trizonia to the west, Delphi-Arachova and some coastal major fault zones have possibly a larger slip rate, as is evident in the seismological and geological data. The area of the northern Gulf of Corinth Rift is comprised of individual and enechelon normal faults with a low slip-rate and evident of a lesser extensional activity. The fault structure seems to deviate from the previous understanding of a general uniform subsidence and inactivity of the area, although there are not enough evidence to assign the tectonic deformation of the area to the Corinth Rift extension or the general back-arc extension of the Aegean area.

The new data reveal a more complex setting for Seismic Hazard since most of the area was considered as a lower hazard in relation with the southern and the major offshore faults. Estimated maximum credible earthquake magnitude for the faults presented in this study is $M=6-7$, according to empirical relationships between fault length and magnitude in the Aegean area (Wells and Coppersmith, 1994; Pavlides and Caputo, 2004). Results from the current study of active faults in the northern Gulf of Corinth were incorporated in the Greek Database of Seismogenic Sources (GreDaSS) in the form of fault models and seismogenic sources (Caputo et al., 2012). More data from paleoseismological studies, fault trenching and dating of geomorpholic surfaces are crucial to the better understanding of the deformation rate and earthquake cycle in the area. More detailed mapping in the inland mountainous area of Fokis to the west and Beotia to the east is necessary to reveal and document poorly mapped or unkown active structures.

Table 1 - Summary of the main Active and Possible Active Faults of the Northern Gulf of Corinth Rift. Fault numbers correspond to Figure 1. Category classifies faults according to the last evident activation of the fault zone.

\begin{tabular}{|c|c|c|c|c|c|}
\hline No - Name & $\begin{array}{c}\text { Length } \\
\mathbf{( K m})\end{array}$ & Category & No - Name & $\begin{array}{c}\text { Length } \\
(\mathbf{K m})\end{array}$ & Category \\
\hline $\begin{array}{c}1 \text { - Agia } \\
\text { Efthimia }\end{array}$ & 7 & $\begin{array}{c}\text { Historical? } \\
(1580 ?)\end{array}$ & 12 - Marathias & 16 & Holocene \\
\hline 2 - Amfissa & 5 & $\begin{array}{c}\text { Late } \\
\text { Quaternary }\end{array}$ & 13 - Kallithea & 5 & Late Quaternary \\
\hline $\begin{array}{c}\text { 3 - Delphi - } \\
\text { Arachova }\end{array}$ & $20-30$ & $\begin{array}{c}\text { Historical - } \\
1870\end{array}$ & 14 - Zaltsa & 14 & Late Quaternary \\
\hline 4 - Antikira & 6 & $\begin{array}{c}\text { Late } \\
\text { Quaternary }\end{array}$ & 15 - Elikonas & 10 & $\begin{array}{c}\text { Middle-Late } \\
\text { Quaternary }\end{array}$ \\
\hline 5 - Sikia & 8 & $\begin{array}{c}\text { Late } \\
\text { Quaternary }\end{array}$ & 16 - Thisvi & 5 & Holocene \\
\hline
\end{tabular}




\begin{tabular}{|c|c|c|c|c|c|}
\hline No - Name & $\begin{array}{c}\text { Length } \\
\text { (Km) }\end{array}$ & Category & No - Name & $\begin{array}{l}\text { Length } \\
(\mathrm{Km})\end{array}$ & Category \\
\hline 6 - Kourmoutsi & 8 & $\begin{array}{c}\text { Late } \\
\text { Quaternary }\end{array}$ & 17 - Domvrena & 15 & Late Quaternary \\
\hline 7 - Makrigialos & 7 & $\begin{array}{c}\text { Late } \\
\text { Quaternary }\end{array}$ & 18 - Neochori & 11 & Holocene \\
\hline 8 - Galaxidi & 6 & Holocene & $\begin{array}{c}19 \text { - Efpalio - } \\
\text { Drosato }\end{array}$ & $5-6$ & Late Quaternary e \\
\hline 9 - Agioi Pantes & 6 & $\begin{array}{c}\text { Late } \\
\text { Quaternary }\end{array}$ & 20 - Amigdalea & 6 & $\begin{array}{l}\text { Middle-Late } \\
\text { Quaternary }\end{array}$ \\
\hline $\begin{array}{c}10- \\
\text { Kokkinovrachos }\end{array}$ & 7 & $\begin{array}{c}\text { Late } \\
\text { Quaternary }\end{array}$ & $\begin{array}{l}21 \text { - Trikorfo - } \\
\text { Filothei } \\
\end{array}$ & 12 & Late Quaternary \\
\hline 11 - Trizonia & 9 & Holocene & 22 - Marathakia & 5 & Late Quaternary \\
\hline
\end{tabular}

\section{Acknowledgments}

Research for this study has been financed by the General Secretariat for Research and Technology of Greece. Discussions and help from Gerassimos Papadopoulos, Theodoros Tsapanos Ioannis Koukouvelas, Vassilis Karastathis, Athanassios Ganas, Alexandros Chatzipetros, Sotiris Kokkalas, Ioannis Tsodoulos, Riccardo Caputo, Nils-Axel Mörner and Vassiliki Zygouri has benefited this study. The first author would like to thank geologists Manolis Patsios, Christos Miriounis and Ioannis Georgiadis for invaluable field assistance. The authors of this study would like also to thank the anonymous reviewers for their constructive comments.

\section{References}

Ambraseys, N., 2009. Earthquakes in the Mediterranean and Middle East: A Multidisciplinary Study of Seismicity up to 1900, Cambridge University Press, London, 910 pp.

Ambraseys, N. and Pantelopoulos, P., 1989. The Fokis earthquake of 1 August 1870, J. Europ. Earthq. Eng., 3, 10-18.

Ambraseys, N.N. and Jackson, J.A., 1990. Seismicity and associated strain of central Greece between 1890 and 1988, Geophys. J. Int., 101, 663-708.

Armijo, R., Meyer, B., King, G.C.P., Rigo, A. and Papanastassiou, D., 1996, Quaternary evolution of the Corinth Rift and its implications for the late Cenozoic evolution of the Aegean, Geophys. J. Int., 126, 11-53.

Bell, R.E., McNeill, L.C., Bull, J.M., Henstock, T.J., Collier, R.E.L. and Leeder, M.R., 2009. Fault architecture, basin structure and evolution of the Gulf of Corinth Rift, central Greece, Basin Research, 21(6), 824-855.

Bernard, A., Hubert-Ferrari, A., Beck, C., Bodeux, S., Tripsanas, E., Sakellariou, D. and De Batist, M., 2015. Active faulting at the western tip of the Gulf of Corinth, Greece, from highresolution seismic data, Marine Geology, 360, 55-69.

Caputo, R., Chatzipetros, A., Pavlides, S. and Sboras, S., 2012. The Greek Database of Seismogen c Sources (GreDaSS): state-of-the-art for northern Greece, Ann. Geophys., 55(5), 859-894.

Celet, P., 1962. Contribution a l'étude géologique du Parnassse - Kiona et d'une partie des régions méridionales de la Grèce continentale, Thèse, Faculté des Sciences de Lille, Annales Geol. Pays Hellen., 13, 1-540.

Chatzipetros, A., Kokkalas, S., Pavlides, S. and Koukouvelas, I., 2005. Palaeoseismic data and thei $\mathrm{r}$ implication for active deformation in Greece, J. Geodyn., 40, 170-188.

de Boer, J.Z. and Hale, J.R., 2000. The geological origins of the oracle at Delphi, Greece. In: McG uire, B. et al., eds. The archaeology of geological catastrophes, Geological Society of Lond on, Special Publication, 171, 399-412. 
Doutsos, T., Kontopoulos, N. and Poulimenos, G., 1988. The Corinth-Patras rift as the initial stage of continental fragmentation behind an active island arc (Greece), Basin Research, 1, 177-190.

Hatzfeld, D., Karakostas, V., Ziazia, M., Kassaras, I., Papadimitriou, E., Makropoulos, K., Voulga ris, N. and Papaioannou, C., 2000, Microseismicity and faulting geometry in the Gulf of Co rinth (Greece), Geophys. J. Int., 141, 438-456.

Lambotte, S., Lyon-Caen, H., Bernard, P., Deschamps, A., Patau, G., Nercessian, A., Pacchiani, F., Bourouis, S., Drilleau, M. and Adamova, P., 2014. Reassessment of the rifting process in theWestern Corinth Rift from relocated seismicity, Geophys. J. Int., 197, 1822-1844.

Leeder, M.R., Mark, D.F., Gawthorpe, R.L., Kranis, H., Loveless, S., Pedentchouk, N., Skourtsos, E., Turner, J., Andrews, J.E. and Stamatakis, M., 2012. A "Great Deepening": Chronology of rift climax, Corinth rift, Greece, Geology, 40, 999-1002.

McNeill, L.C., Cotterill, C.J., Henstock, T.J., Bull, J.M., Stefatos, A., Collier, R.E.L., Papatheodorou, G., Ferentinos, G. and Hicks, S.E., 2005. Active faulting within the offshore western Gulf of Corinth, Greece: implications for models of continental rift deformation, Geology, 33(4), 241.

Ori, G., 1989. Geologic history of the extensional basin of the Gulf of Corinth (MiocenePleistocene), Greece, Geology, 17, 918-921.

Papadopoulos, G.A., ed., 2000. Historical earthquakes and tsunamis in the Corinth rift, central Greece. National Observatory of Athens, Institute of Geodynamics, Publication No 12, 128 pp.

Pavlides, S.B. and Caputo, R., 2004. Magnitude versus fault's surface parameters: quantitative relationships from the Aegean Region, Tectonophysics, 380, 159-188.

Péchoux, P.Y., 1977. Nouvelles remarques sur les versants Quaternaires du secteur de Delphes, Revue de Géographie Physique et de Géologie Dynamique, 19, 83-92.

Piccardi, L., 2000. Active faulting at Delphi, Greece: Seismotectonic remarks and a hypothesis for the geologic environment of a myth, Geology, 28, 651-654.

Piccardi, L., Monti, C., Vaselli, O., Tassi, F., Gaki-Papanastasiou, K. and Papanastasiou, D., 2008. Scent of a myth: tectonics, geochemistry and geomythology at Delphi (Greece), Journal of the Geological Society, London, 165, 5-18.

Stefatos, A., Papatheodorou, G., Ferentinos, G., Leeder, M. and Collier, R., 2002. Seismic reflection imaging of active offshore faults in the Gulf of Corinth: their seismotectonic significance, Basin Research, 14(4), 487-502.

Taylor, B., Weiss, J.R., Goodliffe, A.M., Sachpazi, M., Laigle, M., and Hirn, A., 2011. The structures, stratigraphy and evolution of the Gulf of Corinth Rift, Greece, Geophys. J. Int., 185(3), 1189-1219.

Tsodoulos, I.M., Koukouvelas, I.K. and Pavlides, S., 2008. Tectonic geomorphology of the easternmost extension of the Gulf of Corinth (Beotia, Central Greece), Tectonophysics, 453 , 211-232.

Sebrier, M., 1977. Tectonique récente d'une tranversale a l'Arc Egéen, These de Docteur, Academie de Versailles, Universite de Paris XI, 100 pp.

Stefatos, A., Papatheodorou, G., Ferentinos, G., Leeder, M. and Collier, R., 2002. Seismic reflection imaging of active offshore faults in the Gulf of Corinth: their seismotectonic significance, Basin Research, 14(4), 487-502.

Valkaniotis, S., 2009. Correlation of Neotectonic structures and seismicity in the broader area of Corinth Gulf (Central Greece), PhD thesis, Thessaloniki Aristotle University, 250 pp.

Valkaniotis, S., Papathanassiou, G. and Pavlides, S., 2011. Active Faulting and Earthquake-Induced Slope Failures in Archaeological Sites: Case Study of Delphi, Greece, Earthquake Geology and Archaeology, Science, Society and Critical facilities Vol. 2., In: Grützner, C. et al., eds., $2^{\text {nd }}$ INQUA-IGCP 567 International Workshop, Corinth (Greece) 19-24 September 2011, 255-258.

Wells, D.L. and Coppersmith, K.J., 1994. New empirical relationships among magnitude, rupture length, rupture width, rupture area and surface displacement, Bull. Seism. Soc. America, 84, 974-1002. 